\title{
Pragnienie i zamiar: przyczynek do dystynkcji pojęć ${ }^{1}$
}

\author{
Gerhard Seel (University of Bern, Bern)
}

\section{Uwaga wstępna}

Tomàs Mariano Calvo-Martinez zawsze bronił poglądu, że zgłębianie historii filozofii przynosi pożytek współczesnym debatom filozoficznym, czego doskonałym przykładem były jego własne dociekania. W tym duchu podejmę pewien szczególny problem, znajdujący się w centrum uwagi wciąż żywej dyskusji na gruncie filozofii analitycznej. Dokładniej—podejmę się odpowiedzi na pytanie, czy powinniśmy rozróżniać między pragnieniem a zamiarem, a jeśli tak, to na czym ta różnica miałaby polegać? Do debaty włączę na nowo elementy teorii Arystotelesa wykazując, iż większość deficytów współczesnych teorii działania bierze się właśnie stąd, że pomijają one ważne aspekty tejże teorii.

\section{Tło historyczne}

Nie dziwi fakt, że Arystotelesowska koncepcja czynności duszy powstała pod wpływem Platońskiego podziału duszy na trzy części. Wszelako, Arystoteles wprowadził pewną systematyzację i uporządkował ów podział, wprowadzając dwa podstawowe rozróżnienia. Po pierwsze, wyróżnił dwie główne funkcje duszy: a) wzbudzanie (czy też bycie przyczyną) własnego ruchu, i b) tworzenie wiedzy. Następnie przyjął, że obydwie czynności są realizowane na mocy dwóch odrębnych zdolności: zmysłowej i rozumowej.

Pozwólmy sobie bardziej dogłębnie zanalizować Arystotelesowską koncepcję czynności wywołujących ruch. Będziemy bowiem odnosić się do niej w późniejszych rozważaniach. We fragmencie 433a 9-10 Arystoteles zaznacza: „Okazuje się, że dwie są przyczyny ruchu, pożądanie albo rozum ... " (Arystoteles 1988). Ktoś mógłby pomyśleć, że Arystoteles wprowadza w ten sposób pewien model pragnienia natury intencjonalistycznej resp. „pragnienia-powiązanego-z-przekonaniem”. Jednakże w dalszej części filozof wyjaśnia, że to, co zwie "nous", w przywoływanym fragmencie nie odnosi się do umiejętności stricte teoretycznej, lecz do zdolności pragnienia, które ma naturę rozumową. Co więcej, wyraźnie odróżnia rozumowe pragnienia

1 The Polish translation presented here is based on the original unpublished manuscript What is the Difference Between Desiring and Intending? (c) for the Polish translation by Ethics in Progress Quarterly. (C) for the original English version by Gerhard Seel. 
(boulesis) od pragnień zmysłowych (epithymia). W związku z tym we fragmencie 433a 21-26 powiada:

Wobec tego istnieje tylko jedna przyczyna ruchu, mianowicie władza pożądająca (orektikon; ang. the faculty of desire). Gdyby bowiem dwie były przyczyny ruchu — rozum (nous; ang. thought) i pożądanie (orexis; ang. desire) — poruszałyby na mocy jakiejś wspólnej formy. Tymczasem jest oczywiste, że rozum (nous) nie porusza bez współudziału pożądania (orexis) (bo przecież i wola jest pożądaniem; toteż ile razy ruch odbywa się według pomyślanego planu (logismos; ang. deliberation), odbywa się tym samym w myśl wskazań woli (boulesis; ang. intention). Przeciwnie, pożądanie może wprawiać $\mathrm{w}$ ruch zwierzę niezależnie od jakiegokolwiek rozumowania (logismos), ponieważ pożądanie (epithymia; ang. sensible desire) jest swego rodzaju żądzą (Arystoteles 1988).

W efekcie naszej interpretacji otrzymujemy poniższy, czterodzielny schemat Arystotelesowskiego podziału duszy:

\begin{tabular}{|c|c|c|}
\hline & $\begin{array}{l}\text { Zdolności } \\
\text { związane } \quad \text { Z } \\
\text { postrzeganiem } \\
\text { zmysłowym }\end{array}$ & $\begin{array}{l}\text { Zdolności } \\
\text { intelektualne }\end{array}$ \\
\hline $\begin{array}{l}\text { Funkcja } \\
\text { wyróżniająca }\end{array}$ & $\begin{array}{l}\text { Postrzeganie } \\
\text { zmysłowe }\end{array}$ & $\begin{array}{l}\text { Myślenie } \\
\text { rozumienie }\end{array}$ \\
\hline $\begin{array}{l}\text { Funkcja } \\
\text { dotycząca } \\
\text { ruchu }\end{array}$ & $\begin{array}{l}\text { Pożądanie } \\
\text { zmysłowe }\end{array}$ & $\begin{array}{l}\text { Pożądanie } \\
\text { racjonalne }\end{array}$ \\
\hline
\end{tabular}

Nie do końca wiemy, z jakich powodów filozofowie analityczni w większości odrzucili to przejrzyste i użyteczne rozróżnienie, jednakże możemy się domyślać, że pionierem był Hobbes, a w ślad za nim Hume. Zredukowali oni Arystotelesowskie czterodzielne rozróżnienie w sposób radykalny, przypisując zdolnościom racjonalnym jedynie funkcję poznania teoretycznego i utwierdzając się $w$ przekonaniu, że ludzkie działanie jest ostatecznie wypadkową pewnych funkcji naszej zmysłowości. Według Hume'a zatem „rozum jest odkrywaniem prawdy i fałszu” (Hume 1963, III 244), podczas gdy ostateczną przyczynę działania stanowi pewnego rodzaju percepcja. Powiada on dalej, że „w ludzkim umyśle zakorzeniona jest percepcja przykrości i przyjemności jako główna sprężyna i czynnik poruszający wszystkich działań" (Hume 1963, I 62). Należy zauważyć, że poglądy Hume'a nie znalazły poparcia u wszystkich współczesnych mu filozofów. Choćby Kant utrzymał czterodzielny podział duszy, a nawet go wzmocnił. Jednakże wpływ Hume'a na filozofię analityczną okazał się dominujący; większość filozofów podąża dziś właśnie za nim, tymczasem kontynuują tradycję wywodzącą się od 
Arystotelesa i Kanta. W rzeczy samej, starając się objaśnić istotę działania, większość współczesnych filozofów korzysta z tzw. intencjonalnego modelu pragnienia resp. modelu utożsamiającego pragnienie z przekonaniem, podług którego motorem ludzkich działania jest pożądanie jakiegoś stanu rzeczy i przekonanie, że inny określony stan rzeczy jest środkiem niezbędnym do zaistnienia tego pierwszego. W dalszej części artykułu postaram się wykazać, że model redukcjonistyczny jest fałszywy w porządku empirycznym, a w porządku eksplanacyjnym okazuje się niewystarczający, a ponadto, że musimy wyróżnić dwie praktyczne funkcje duszy, tj. zdolności zmysłowe (pragnienia; ang. desire) i zdolności racjonalne (zamiary; ang. intention).

\section{Czym jest pragnienie?}

Pierwszą wskazówką przemawiającą za tym, że pomiędzy pragnieniem i zamiarem zachodzi różnica niech będzie fakt, iż używamy różnych typów wypowiedzi, aby je wyrazić. Jednakże dokładne znaczenie tych wyrażeń zależy od kontekstu i nie jesteśmy w stanie nakreślić wyraźnej linii granicznej między nimi. Potwierdza to w szczególności specyfika języka angielskiego. Być może fakt ten wyjaśnia również, dlaczego niektórzy anglojęzyczni filozofowie całkowicie zarzucili omawiane rozróżnienie-jak już zauważyliśmy wcześniej. Rozważmy wobec tego poniższą, egzemplaryczną (w żadnym razie nie wyczerpującą) listę wyrażeń anglojęzycznych:

1. Chciałbym kieliszek wina (I would like a glass of wine).

2. Kocham pływać (I love to swim).

3. Poszukuję romansu (I am looking for a love affair).

4. Gdybym tylko mógł ją zobaczyć (If I only could see her).

5. Chciałbym miejsce przy przejściu (I wish an aisle seat).

6. Chciałbym podróżować z tobą (I wish to travel with you).

7. Chciałbym mieć tysiąc Euro (I wished I had a thousand Euros).

8. Chciałbym poruszać się z większą lekkością (I wish I were lighter on my feet).

9. Wszyscy pragniemy pokoju (We all desire peace).

10. Chcę nowy konwertor (I covet the new convertible).

11. Pożądał sławy i fortuny (He was craving fame and fortune).

12. Byłoby cudownie, gdybyś mnie odwiedził (It would be lovely if you came to see me).

13. Pragnę twojej miłości (I am longing for your love).

14. Boję się, że umrę (I am afraid to die).

15. Mamy nadzieję, że kryzys szybko minie (We hope that the crisis will be over soon).

16. Nie możemy się doczekać, żeby cię zobaczyć (We are looking forward to seeing you). 
17. Oddaj mi mój paszport (Give me my passport back).

18. Chcę odejść (I want to leave).

19. Zamierzam do ciebie napisać (I am going to write to you).

20. Zawsze chcieliśmy mieć dziecko (We have always wanted a child).

21. Chcę piwo (I want a beer).

22. Nie mam zamiaru wyrządzić krzywdy (I intend no harm).

23. Zamierzałem wyjść z przyjęcia przed północą (I intended leaving the party before midnight).

24. Chciała, żebym usłyszał tamten komentarz (She intended me to hear the remark).

25. Zawsze będę cię kochał (I will always love you).

26. Nie pozwolę mu zniszczyć przyjęcia (I won't have him ruining the party).

27. Pozwolisz mi powiedzieć? (Will you let me speak?)

Wyrażenia od 1 do 16 są używane zwykle do artykulacji pragnień, a wyrażenia od 17 do 27 do artykulacji zamiarów. Jakkolwiek, jak już wcześniej zaznaczyłem, nie ma między nimi wyraźnej linii granicznej. Warto zauważyć, że większość tych wyrażeń to zdania pierwszoosobowe $(1,2,3,4,5,7,8,9,10$, $11,14,15,16,17)$. Jedno (18) ma postać imperatywu. Niekiedy przedmiot wyrażonego pragnienia czy zamiaru jest obiektem materialnym $(1,4,5,9,11$, 12), innym razem jest działaniem wyrażonym w bezokoliczniku $(2,6,9,15$, 17), jeszcze innym razem jest określonym stanem rzeczy $(2,3,4,6,8,10,13$, 16). Nie ma wątpliwości, że wyrażenia bezokolicznikowe to uproszczone określenia stanów rzeczy. Zatem możemy zredukować trzy wyżej wymienione typy przedmiotów do dwóch. Ktoś mógłby pokusić się o dalszą redukcję liczby przedmiotów, argumentując, że wyrażenia odnoszące się do obiektów materialnych są również uproszczeniami stanów rzeczy. Zatem wyrażenie „kieliszek wina” w pierwszym przykładzie jest skrótem dla wyrażenia „Mam kieliszek wina". Zgadzam się z tym. Jeśli uda nam się zredukować typy przedmiotów pragnień i zamiarów, dojdziemy do wniosku, że właściwym przedmiotem pragnień są-reprezentowane językowo-stany rzeczy. W tym kontekście pragnienia będą miały charakter racjonalny i nie będą różnić się od intencji. Jednakże przedstawiony pogląd nie znajduje uznania w filozoficznej tradycji. Dla przykładu, Arystoteles utrzymuje, że przedmiot zmysłowego pragnienia (orexis) jest albo wyobrażeniem (phantasma), albo odczuciem (aisthesis). Wyobrażenia są zmysłowymi reprezentacjami czegoś, co niesie ze sobą przyjemność; w odczuciach zaś dana jest przyjemność sama przez się.

Możemy wyjaśnić różnicę pomiędzy tradycyjnym i współczesnym poglądem na tę kwestię powołując się na fakt, że starożytni za punkt wyjścia takiej analizy przyjęli teorię psychologiczną, natomiast współcześni za punkt wyjścia obierają wyrażenia językowe na podobieństwo przytoczonych na powyższej liście. Kogoś, kto postąpi tak, jak ci drudzy, zabieg ten nieuchronnie przywiedzie do racjonalnej koncepcji przedmiotów pragnień. Mimo, że 
sympatyzuję z podejściem tradycyjnym, nie powinienem posuwać się do zanegowania twierdzenia, że stany rzeczy mogą być przedmiotami pragnień. Będę jednak nalegał na to, by przyjąć, że w takim przypadku zawsze mówimy o jednostkowych stanach rzeczy, którym towarzyszy wyobrażenie konkretnego scenariusza; powiedzmy, że będzie to wyobrażanie sobie miłosnych uniesień z Marią na plaży.

W dalszej części artykułu postawię cztery pytania dotyczące statusu pragnienia.

1. Czy jest konieczne, aby podmiot odczuwający pragnienie był tego świadom? (Is it necessary that the subject of a desire is aware of her desire?)

2. Czy pragnienia są postawami propozycjonalnymi? (Are desires propositional attitudes?)

3. Czy pragnienia implikują sądy wartościujące? (Do desires imply value judgments?)

4. Czy pragnienia implikują motywację do działania? (Do desires imply a motivation to act?)

1. Czy jest konieczne, aby pragnący czegoś podmiot był świadom swego pragnienia, czy też istnieją także nieuświadomione stany pragnienia lub chociażby nieuświadomione dyspozycje do osiągania stanów pragnienia? Fakt, że możemy artykułować nasze pragnienia w formie wyrażeń językowych, zdaje się wskazywać na to, że jesteśmy-przynajmniej $w$ takich przypadkach—świadomi naszych pragnień. Ci, którzy utrzymują, że jesteśmy z konieczności świadomi swoich pragnień nazywani są "fenomenalistami”. Wyróżniamy fenomenalizm „silny” i „słaby“. Reprezentanci silnego fenomenalizmu podtrzymują następujący pogląd:

T1: $x$ pragnie $p$, jeśli $x$ jest przekonany, że $x$ pragnie $\mathrm{p}(\mathrm{T} 1 \mathrm{x}$ desires that $\mathrm{p}$ if $\mathrm{x}$ believes that $\mathrm{x}$ desires that $\mathrm{p}$ ).

Zdanie T1 jest zbudowane na słynnej tezie: „x czuje ból, jeśli x jest przekonany, że x czuje ból." Można by jednak osłabić T1 i zastąpić je poniższą propozycją:

T2: $x$ pragnie $p$, jeśli istnieje choćby jeden moment tx taki, że $\mathrm{x}$ jest przekonany $\mathrm{w} \mathrm{tx}$, że $\mathrm{x}$ pragnie $\mathrm{p}$ (T2 $\mathrm{x}$ desires that $\mathrm{p}$ if there is at least one moment of time $\mathrm{t} x$ and $\mathrm{x}$ believes at $\mathrm{t} x$ that $\mathrm{x}$ desires that $\mathrm{p}$ ).

Ci, którzy podtrzymują T2, reprezentują słaby fenomenalizm. ${ }^{2}$ Właściwe pytanie brzmi natomiast tak: czy słuszne jest T1, czy też może T2?

Najbardziej znamienitym filozofem, który odmawia słuszności którejkolwiek z tych propozycji, jest Michael Smith. Po pierwsze, występuje on

2 Anthony Kenny zdaje się bronić słabego fenomenalizmu w (1963, 218; 1974, 32). Zob. także Roughley $(2006,128)$, który nazywa omawiane stanowisko „świadomym okurentyzmem" (CO), nie akceptując go jednak osobiście. 
przeciw „silnemu fenomenalizmowi”3 i uważa, że jest to podejście błędne, a następnie-w drugim kroku—przypuszcza atak na „słaby fenomenalizm”. Nie jestem w stanie przytoczyć w tym miejscu szczegółowej argumentacji Smitha; sądzę, że jest ona niekonkluzywna. Mogę co najwyżej nakreślić mój własny pogląd: musimy odróżnić pragnienie jako dyspozycję z jednej strony od pragnienia jako aktu psychicznego $\mathrm{z}$ drugiej. Jedynie w tym drugim znaczeniu pragnienie implikuje samoświadomość; tymczasem pragnienie w pierwszym znaczeniu samoświadomości nie implikuje, o ile nie uświadamiamy sobie tej dyspozycji w odpowiednim akcie psychicznym. Jakkolwiek, jeśli nigdy nie zaobserwujemy takiego aktu, możemy stąd wywnioskować, że taka dyspozycja w ogóle nie zaistniała.

2. Czy wyrażam postawę propozycjonalną, mówiąc: „Chciałbym wygrać na loterii", czy też wyrażam afekt, emocję bądź uczucie? Jak wcześniej wspomniałem, filozofowie od Arystotelesa do Hume'a optowali za tym drugim stanowiskiem, podczas gdy dzisiaj większość filozofów podąża za Stevensonem i Davidsonem, podtrzymując pierwsze stanowisko.

Przede wszystkim powinienem wyjaśnić, co wyraża stanowisko drugie i skąd się bierze jego atrakcyjność. Niechaj dane mi będzie ponownie odwołać się do mojej listy wyrażeń językowych, związanych z pragnieniami. W sposób oczywisty zawierają one dwa elementy: wyrażenie opisujące stan rzeczy będący przedmiotem pragnienia oraz wyrażenie-zwykle $\mathrm{w}$ pierwszej osobie-samego pragnienia. Jakkolwiek, nie jest jasne, jakie jest właściwie znaczenie wyrażeń tego ostatniego rodzaju. Nie mogło więc umknąć uwadze filozofów języka to, że wyrażenia opisujące pragnienia są uderzająco podobne do wyrażeń innego rodzaju, mianowicie takich, które opisują przekonania. Wyrażenia jednego i drugiego typu składają się z dwóch elementów: pierwszy opisuje stan rzeczy będący przedmiotem przekonania, drugi zaś daje wyraz przekonaniu. Drugi, zgodnie z tradycją, rozumiany jest jako wyraz postawy mówiącego wobec rozważanego przezeń stanu rzeczy. Rozważa on zaś to, że stan rzeczy zachodzi lub też, że odnośne twierdzenie jest prawdziwe. Nie dziwi wobec tego, że w obliczu analogicznej konstrukcji wyrażeń opisujących pragnienia filozofowie języka tacy, jak Stevenson czy Davidson, rozumieli przez takie wyrażenia również artykulację postawy podmiotu wobec jakiegoś stanu rzeczy. Jedyną różnicę pomiędzy przekonanie i pragnienie wprowadza tzw. „kierunek dostosowania“ (direction of fit). W przypadku przekonania mówiący utrzymuje, że jakiś stan rzeczy zachodzi, zaś w przypadku pragnienia mówiący pragnie, aby jakiś stan rzeczy zachodził (In the case of believing the speaker holds that a state of affairs is the case, in the case of desiring the speaker wants that a state of affairs be the case).

Opisane stanowisko jest 'prima facie' nader przekonujące. Tym niemniej, będę starał się je obalić. Do strategii, która ma doprowadzić mnie do tego celu,

${ }^{3}$ M. Smith (1994) używał mylącego określenia „fenomenologiczny”. 
należy podzielenie się wątpliwościami pod adresem analogii pomiędzy przekonaniami i pragnieniami. W rzeczy samej, jestem skłonny przyznać, że przekonanie posiada określone właściwości semantyczne i logiczne, jakich pozbawione jest pragnienie; można je odnaleźć dopiero w zamiarze, o czym będzie mowa dalej (poczynione dotąd ustalenia posłużą nam za argumenty w późniejszych rozważaniach nad konieczności odróżniania pragnienia od zamiaru).

W przypadku przekonania napotykamy nader osobliwy paradoks, który po raz pierwszy opisał i poddał analizie G. E. Moore (1942, 544; 1944, 204). Zauważył on, że powiada się niekiedy: „Tak, pada, ale nie jestem co do tego przekonany” lub „Tak, pada, ale jestem przekonany, że tak nie jest”. Takie zdania nie są sprzeczne, jak słusznie zauważył B. Williams $(1970,137)$ i wielu innych. Niemniej jednak, osobę formułującą takie wypowiedzi piętnujemy zwykle jako irracjonalną, ponieważ tworzy ona coś, co K.-O. Apel nazwał „sprzecznością performatywną“.4 Rzeczywiście, połączone w ten sposób zdania-choć niesprzeczne-są nieuchronnie fałszywe.

Pytanie brzmi, czy analogiczny paradoks da się wykryć w przypadku wypowiedzi złożonych ze zdań wyrażających pragnienie (the utterance of desire-sentences). Czy można napiętnować kogoś za irracjonalizm, słysząc taką oto wypowiedź: „Niech pada, ale wolałbym, żeby świeciło słońce”? Ponownie nie ma tu sprzeczności, ale czy taka wypowiedź wynika z irracjonalności? Nie sądzę, mimo, że brzmi ona bardzo dziwnie. Przyczyna tej osobliwości tkwi w tym, że-w przeciwieństwie do twierdzeń i zdań wyrażających przekonanianie możemy wprowadzać dla przedstawionych zdań semantyki, która pozwoliłaby wykazać pragmatyczną „sprzeczność performatywną“. Dla tych, których powyższy argument nie przekonuje, można dodatkowo wykazać, że wyrażanie pragnień nie oznacza wysuwania roszczeń ważnościowych (validity-claim). Przemawia za tym również fakt, że możemy pragnąć urzeczywistnienia jakiegoś stanu rzeczy pomimo, iż wiemy, że ów pożądany stan jest niemożliwy do osiągnięcia. Mogę np. powiedzieć, że „Chciałbym żyć w czasach Jezusa". Taka wypowiedź nie jest irracjonalna. Dlatego wspomniane wyżej typy wypowiedzi nie dyskwalifikują ich autora jako osoby irracjonalnej.

Jeśli w tym miejscu mam rację, pragnienie jest w swej istocie czymś odmiennym od przekonania, a także od zamiaru-w perspektywie roszczeń autora wypowiedzi do bycia podmiotem racjonalnym. Różnica ta czyni nieprawdopodobnym to, że pragnienie miałoby być postawą propozycjonalną na podobieństwo przekonania..$^{5} \mathrm{O}$ ile jednak nie jest postawa propozycjonalną,

4 Podjęto kilkakrotnie próbę wprowadzenia semantyki, która wyjaśniałaby tę sprzeczność; ostatnia należy do A. Hieke.

${ }^{5}$ Wyrażenie „postawa propozycjonalna” jest w każdym razie mylące. Mogę przejawiać krytyczną postawę wobec rządu czy kościoła, ale nie przejawiam postawy dotyczącej sądu (proposition). To, czym dysponuję, to dyspozycja, która czyni mnie zdolnym do odpowiedzi na pytanie, czy sąd jest prawdziwy: „tak” lub „nie”. 
to czym? Jedną z możliwości znalezienia odpowiedzi na to pytanie jest powrót do teorii Arystotelesa teorii i sprawdzenie, czy może ono być emocją lub uczuciem. Możliwość tą rozważę w kolejnej części artykułu.

3. Czy wyrażenia dotyczące pragnień implikują „sądy wartościujące” —jak utrzymuje Davidson-czy też implikują odniesienie do pewnych zmysłowych doświadczeń, takich jak przyjemność i przykrość, jak postulował Arystoteles? W pierwszym kroku zarysuję i gruntownie objaśnię tezę Davidsona. Davidson utrzymuje, że pragnienie ziszczenia się jakiegoś stanu rzeczy pociąga za sobą z konieczności sąd stanowiący, że pożądany stan rzeczy ma wartość pozytywną. Wynika to z faktu, że Davidson traktuje sądy wartościujące jako wyrażenia językowe dotyczące pragnień na podobieństwo sądów deskryptywnych traktowanych po prostu jako wyrażenia językowe odnoszące się do przekonań: „Jeśli wyrażone wprost (explicit) sądy wartościujące prezentują postawy aprobujące (pro-attitudes), wszystkie tego typu postawy mogą być wyrażone poprzez sądy wartościujące, w których tkwią przynajmniej implicite" (Davidson 1978, 86) ${ }^{6}$. Oznacza to, że Davidson utrzymuje-jak nazywamy to we współczesnej, technicznej terminologii-stanowisko internalistyczne. Aczkolwiek, według Davidsona, podstawowym aktem psychicznym jest akt pragnienia, a sąd wartościujący jest wyłącznie jego językowym wyrazem. W mojej opinii Davidson posługuje się niewłaściwą semantyką $\mathrm{w}$ odniesieniu do sądów wartościujących, jeśli w ogóle jakąś zakłada7. Zadaniem sądów wartościujących nie jest bowiem wyrażanie pragnień, ponieważ funkcjonują one raczej jako kryteria decyzyjne (decision criteria) i jako takie-podnoszą one jedynie w stopniu minimalnym roszczenie co do ważności i racjonalności.

Aby podważyć stanowisko Davidsona, wystarczy przyjrzeć się następującemu zjawisku: często pragniemy czegoś, co-ze względu na nasze sądy wartościujące-nie jest godne pożądania, lub też, pomimo, że żywimy silne przekonania co do pewnej rzeczy, iż jest ona wysoce wartościową, nie potrafimy wytworzyć wobec niej pragnienia, aby ją urzeczywistnić. Klasyczne przykłady obrazujące powyższe tendencje opisali już starożytni, demaskując je jako przejawy słabej woli.

W tym miejscu ponownie użyteczne będzie porównanie stanowiska Davidsona z wcześniejszymi poglądami dotykającymi tych kwestii. W słynnym fragmencie Arystoteles (1984, 1072 a 29) pyta: czy pożądamy czegoś ponieważ jest dobre, czy też coś jest dobre, ponieważ tego pożądamy? Jego odpowiedź brzmi: „Pożądamy pewnej rzeczy z reguły dlatego, że wydaje nam się dobra, a nie dlatego wydaje się nam dobra, że jej pożądamy" (1072a). Dlaczego właściwie coś zdaje się być dobre? Arystoteles odpowiada: ponieważ

${ }^{6} \mathrm{~W}$ przekładzie A. Mathiesen.

7 Cp. Smith uważa, że stanowisko Davidsona jest „znacząco błędne” (profoundly wrong) $(1994,138)$. 
przynosi nam przyjemność. W istocie, Arystoteles utrzymuje, że przyjemność i przykrość są tym rodzajem zmysłowych odczuć, które uświadamiają nam, że coś jest dobre lub-odpowiednio-że coś jest złe ${ }^{8}$. Odczucie to implikuje bezpośrednio akt pragnienia lub, odpowiednio, akt unikania. Według Arystotelesa za każdym razem, gdy odczuwamy przyjemność, pragniemy, by jej uczucie trwało, a kiedy odczuwamy przykrość, pragniemy, by jej odczucie zakończyło się.

Zauważmy, że doświadczenie przyjemności i przykrości zależy od rozmaitych innych zjawisk. Mogą wypływać z potrzeb cielesnych, takich, jak głód czy pragnienie, mogą wyrastać z emocji, tj. gniewu, nienawiści lub miłości; mogą też pojawiać się wraz z osiągniętym sukcesem lub doznaną porażką jako dodatkowe efekty naszych dążności; i mogą wreszcie towarzyszyć wszelkiej naszej aktywności jako oznaki naszego mistrzostwa i doskonałości w miarę ich stopniowego osiągania.

Odnośnie do istoty pragnienia zgadzam się z Arystotelesem: pragnienie jest zakorzenione w odczuciu przyjemności i przykrości. Pragniemy pewnego stanu rzeczy, ponieważ wytwarzamy odczucie wiążące ten stan rzeczy $\mathrm{z}$ przyjemnością. Nadto, możemy również pragnąć przyszłych stanów rzeczy. Jest to jednak sprawa bardziej skomplikowana. Aby pragnąć przyszłych stanów rzeczy, należy spełnić trzy warunki:

1. Musielibyśmy umieć wyobrazić sobie konkretny, przyszły stan rzeczy, a w terminologii Arystotelesa: wyrobić sobie i posiadać jego wyobrażenie (phantasma).

2. Musielibyśmy wydobyć $\mathrm{z}$ przeszłości inne doświadczenie, potwierdzające, że podobny stan rzeczy był dla nas źródłem przyjemności.

3. Musielibyśmy oczekiwać, że osiągnięcie podobnego stanu rzeczy $\mathrm{w}$ przyszłości także dostarczy nam przyjemności.

Nie ma wątpliwości co do tego, że nakładanie się przyczynowości mającej pierwotnie źródło w przyjemności minionej oraz przyczynowości, która ma źródło w przyszłych stanach rzeczy, należy do sfery aktów psychicznych, które zakładają minimum racjonalności. W takim i tylko takim przypadku pragnienie będzie implikować rozumowanie.

${ }^{8}$ Cf. O duszy, 431 a 8-14: "Postrzeganie zatem cechuje podobieństwo do pojedynczego słowa i prostego pojęcia. Gdy jednak [przedmiot postrzeżony] jest przyjemny lub przykry, [dusza] dąży do niego lub przed nim ucieka, jak gdyby wydawała o nim sąd twierdzący lub przeczący; a odczuwanie przyjemności lub przykrości jest reakcją władzy zmysłowej (złożonej z pierwiastków dobranych w odpowiedniej proporcji) na dobro lub zło jako takie. Odraza i pożądanie gdy aktualnie istnieją, są identyczne; również władza pożądająca i władza odczuwająca odrazę nie różnią się ani między sobą, ani od władzy spostrzegawczej-tylko ich istota jest odmienna" (Arystoteles 1988). 
Jeśli nie mylę się w tej kwestii, to przyjdzie nam uznać kolejną osobliwość pragnienia. Ponieważ nie jestem w stanie odczuwać przyjemności i przykrości które odczuwa inna osoba, uczucia te są istotowo doświadczeniami zindywidualizowanymi i prywatnymi (private). Jeśli, jak wskazywałem powyżej, pragnienie zakorzenione jest w odczuciu przyjemności, to powinno ono-konsekwentnie-pozostawać czymś jednostkowym i prywatnym. Oznaczałoby to jednak, że pragnienie jest swej istoty egoistyczne. Wszyscy zdajemy sobie sprawę, że Hume nie podzielał tego stanowiska. Utrzymywał bowiem, że nasze pragnienia mogą mieć charakter zarówno egoistyczny, jak i altruistyczny. Wszelako, Kant wykazał, że „altruistyczne” pragnienia Hume'a są egoistyczne na głębszym poziomie, ci bowiem, którzy żywią pragnienia altruistyczne, czerpią przyjemność z dobrobytu innych.

4. Czy twierdzenie „x pragnie p” implikuje zdanie „x jest zmotywowany do osiągnięcia p", czy też możliwe jest pragnąć czegoś, a jednocześnie być pozbawionym motywacji do osiągnięcia tego czegoś? Powyższe pytanie można również wyrazić nieco inaczej: czy koniecznie jest tak, że jeśli x pragnie p, to $\mathrm{x}$ ujawnia pewien cielesny proces (bodily process) lub działalność, postrzegane zwykle jako czynniki przyczyniające się do urzeczywistnienia p?

Gwoli większej przejrzystości już na samym początku odpowiadam twierdząco na postawione pytanie, choć wielu filozofów analitycznych nie zgodziłoby się z tym. Zwykle wytaczają oni w takich okolicznościach dwa kontrargumenty: a) tzw. "przypadki bycia jedynie obserwatorem (mere spectators cases)", i b) przypadki działań niemożliwych, których treść (propositional content), tj. przedmiot pragnienia, wyklucza jakąkolwiek możliwość realizacji przez podmiot (nie może się on $\mathrm{w}$ żaden sposób przyczynić do owej realizacji).

Typowym przykładem pierwszego kontrargumentu będzie sytuacja, w której to kibic drużyny piłkarskiej ogląda w telewizji mecz swojej drużyny i pragnie, by zdobyła ona bramkę. Odnosząc się do tego przykładu, Roughley twierdzi, że tamten człowiek pragnie co prawda, aby jego drużyna strzeliła gola, ale nie pragnie sam przyczynić się do tego osiągnięcia, gdyż zdaje sobie sprawę, że jest to niemożliwe. Dlatego też nie ma on motywacji do działania. Jednakże $\mathrm{w}$ argumencie tym pragnienie pomieszane jest $\mathrm{z}$ zamiarem. Jak już zauważyliśmy, w przypadku pragnienia całkowicie nieistotne jest pytanie o to, czy jego przedmiot jest osiągalny, czy nie. Należy raczej zapytać, czy podmiot przejawia jakąkolwiek cielesną aktywność sugerującą jego motywację gwoli działania. W związku z tym przykład obserwatora meczu potwierdza w zasadzie moje stanowisko. Nierzadko bowiem można zaobserwować, że kibic oglądający mecz mimowolnie i nieświadomie wykonuje ruchy i kopnięcia, jakby próbował strzelić piłką. To zaś w oczywisty sposób świadczy o tym, że posiada on motywację do działania. 
Uogólniając nieco, zauważyć należy, że ekspresja pragnienia, czy to za pomocą słów, czy gestów, świadomie lub nie, jest częścią łańcucha przyczynowego, który prowadzi do urzeczywistnienia przedmiotu pragnienia. I tak, płacz dziecka jest elementem przyczynowości w łańcuchu przyczynowym, który sprawia ostatecznie, że przyjdzie mama i je nakarmi. Tak samo dzieje się, kiedy powiemy: „Chciałbym dostać filiżankę herbaty”, uruchamiając tym samym łańcuch przyczynowy prowadzący do tego, że zostaje nam podana filiżanka herbaty. Dlatego też błędem jest opisywanie funkcji wyrażania przez kogoś pragnienia w kategoriach przekazywania drugiej osobie informacji, że ktoś żywi jakieś pragnienie; jest to raczej „wezwanie innych do zaspokojenia pragnienia”. Stąd, wyrażanie pragnień posiada nie teoretyczną, lecz praktyczną funkcję.

Znacznie trudniej będzie obalić kontrargumenty drugiego typu, używane przez Roughley'ego. Roughley podaje przykład ojca, którego pragnieniem jest dotrzymywanie przez syna obietnic z własnej inicjatywy, bez niczyjej pomocy. Gdyby ojciec przypomniał synowi o złożonej obietnicy, zniweczyłby możliwość urzeczywistnienia własnego pragnienia. Wiedząc o tym, nie ma on żadnej motywacji do przypominania synowi o obietnicy, co oznacza, że jego pragnienie nie wiąże się z motywacją do działania, a przynajmniej tak argumentuje Roughley. Ponownie jednak padł on tutaj ofiarą pomieszania pragnienia z zamiarem. Świadomość, że nie jest się $\mathrm{w}$ stanie zrealizować pragnienia mocą własnego działania, niekoniecznie pociąga za sobą rezygnację z prób takiej realizacji. Dobrym tego przykładem jest przypadek zabiegania o komplementy. Mimo, że wiadomo powszechnie, iż komplementy tracą na wartości, gdy nie są spontaniczne, kobiety-i nie tylko one-starają się je sprowokować poprzez odpowiednie gesty czy spojrzenia. Widzimy zatem, że ich pragnienie otrzymania komplementu jest sprzężone z motywacją do podjęcia wysiłku w celu osiągnięcia pożądanego efektu; i nie przeszkadza w tym świadomość, że efekt jest w ten sposób nieosiągalny.

Wyciągając wnioski $\mathrm{z}$ tych rozważań, jestem skłonny zdefiniować pragnienia jako motywy. Popychają nas do one do urzeczywistniania upragnionych przedmiotów. Zazwyczaj urzeczywistniamy taki przedmiot za sprawą naszych działań. Są one ogniwami łańcucha przyczynowego, na którego końcu znajduje się urzeczywistnienie upragnionego przedmiotu. Wyrażenie przez kogoś pragnienia jest zwykle ogniwem inicjującym ten łańcuch, a fakt ten pociąga za sobą świadomość działającego (agent) względem wyrażanego przezeń pragnienia (jakkolwiek istnieją również pragnienia nieuświadomione). Jest to zresztą przyczyna, dla której pragnienia wyraźnie pojawiają się $w$ pierwszoosobowych eksplanacjach działań. Nie mogę użyć dla eksplanacji mojego działania czegoś, czego nie jestem świadom, chyba, że traktuję samego siebie jako przedmiot własnej analizy psychologicznej. Jednakże w ostatnim przykładzie dostarczam eksplanacji trzecioosobowej zamiast pierwszoosobowej. 
Jest to właśnie powód, dla którego bronię stanowiska 'słabego fenomenalizmu', odrzucając jednocześnie interpretacje pragnień oparte na „postawach propozycjonalnych” i „wyrażeniach wartościujących (valueexpressions)", choć są one naturalnymi sojusznikami fenomenalistów. Pozwolę sobie teraz podać definicję pragnienia opartą na przedstawionej powyżej argumentacji:

$\mathrm{s}$ pragnie $\mathrm{p}$, jeśli s posiada motyw, aby urzeczywistnić $\mathrm{p}$, oraz dyspozycję do bycia świadomym-jako uczucie-własnego motywu do urzeczywistnienia $p$.

( $s$ desires that $p$ if $s$ has a motive to bring $p$ about and a disposition to be aware-in form of a feeling - of her motive to bring $p$ about).

\section{Czym jest zamiar lub wola?}

Pozwolę sobie wyjaśnić istotowe własności zamiarów poprzez skontrastowanie ich z własnościami pragnień. Jaka jest różnica między tymi rodzajami aktów mowy?

1. Agent A zapytany, czy pragnie p, odpowiada: „Tak, pragnę p”.

2. Agent A zapytany, czy zamierza p, odpowiada: „Tak, zamierzam p”.

Jest całkiem oczywiste, że przedstawione akty mowy nie różnią się ze względu na ich treść propozycjonalną. Stąd też, jeśli w ogóle zachodzi między nimi jakaś różnica, musimy jej szukać gdzie indziej:

1. Poprzez pierwszy akt mowy-jeśli nie jest on aktem li tylko deskryptywnym-A wyraża tyle, że podejmuje wysiłek na rzecz realizacji p. Jak już zauważyliśmy wcześniej, wyrażenie przez kogoś pragnienia jest pierwszym ogniwem łańcucha przyczynowego prowadzącego do ewentualnego urzeczywistnienia pożądanego stanu rzeczy.

W przypadku drugiego aktu mowy sytuacja jest zdecydowanie inna. Może dotyczyć przypadku, kiedy A zapytany, czy zamierza p, jeszcze nie podjął decyzji. Pytanie stawia go w sytuacji decyzyjnej, kiedy to musi wybrać, czy zamierza p, czy nie. W takim przypadku jego odpowiedź będzie niczym innym aniżeli efektem decyzji podjętej przez A, aby czynnie przeprowadzić zamiar. Wobec tego A jest w pełni odpowiedzialny za swój zamiar, gdy tymczasem w przypadku pragnienia pozostałby odpowiedzialny jedynie częściowo i w ograniczonym stopniu.

2. Są dwa typy rezultatów procesu podejmowania decyzji: akty wyrażające przekonania i akty wyrażające zamiary. Poprzez obydwa rodzaje aktów wyrażam pewne zaangażowanie lub podejmuję pewne zobowiązania, poddając się w ten sposób pewnej powinności. Stąd też przekonania i zamiary są przedmiotem norm racjonalności (cf. Seel 2004, 396-412). 
Czym są zobowiązania, które wytwarzam mocą aktów wyrażających przekonania i zamiary?

1. Pierwszy rodzaj zobowiązania obejmuje trzymanie się swoich przekonań i zamiarów oraz niezmienianie i nieodwoływanie ich bez słusznego powodu. Na przykład gdy ktoś po głębokim namyśle podejmuje zamiar złapania następnego pociągu, a potem, nawet bez wszczęcia jakiegokolwiek działania, ni stąd ni zowąd oznajmia, że nie złapie pociągu, czyż nie mamy powodu, by podejrzewać tę osobę o zachowanie irracjonalne? I znów widoczny jest tutaj kontrast między pragnieniem a zamiarem, podobnie jak wówczas, gdy ktoś oznajmia, że pragnie napić się wina, a potem nagle traci wszelkie zainteresowanie dla ziszczenia swojego pragnienia: a przecież nie posądzamy go o zachowanie irracjonalne.

2. Drugi rodzaj zobowiązania dotyczy upewnienia się, czy moje przekonania i zamiary nie stoją w sprzeczności z innymi moimi zamiarami i przekonaniami. Poprzez akt zamierzenia p nakładam na siebie powinność koniecznego ujęcia $w$ mych zamiarach wszelkich stanów rzeczy, implikowanych przez p. Co więcej, nakładam na siebie obowiązek zmiany mojego zamiaru, jeśli dojdę do przekonania, że albo samo p, albo któraś z jego implikacji jest niemożliwa do osiągnięcia.

3. Trzeci rodzaj zobowiązania dotyczy podjęcia próby urzeczywistnienia stanu rzeczy, który jest przedmiotem odnośnego zamiaru. Mówiąc: "Zamierzam p" ( $I$ intend that $p$ ), obliguję samego siebie do uczynienia wszystkiego, co możliwe, aby urzeczywistnić p. W zasadzie, z chwilą, gdy zamiar uformował się wskutek procesu decyzyjnego, zaczyna on służyć jako kryterium dla dalszych decyzji dotyczących wyboru środków, które chcemy podjąć dla osiągnięcia celu. Aczkolwiek, zamiar nie jest motywem, lecz powodem (it is a reason). Mogę swobodnie wybrać pomiędzy honorowaniem lub niehonorowaniem własnych zobowiązań. Zamiar staje się motywem dopiero wówczas, gdy decyduję się podjąć zobowiązanie i działać zgodnie z nim.

Pozwolę sobie na podsumowanie:

1. Zamiary są formowane i zmieniane w rezultacie podejmowania decyzji, natomiast pragnienia wyrastają z doświadczeń przynoszących przyjemność.

2. Pragnienia są motywami, zamiary zaś powodami działania.

3. Ponieważ 1. i 2., to zamiary podlegają normom racjonalności w sensie wyłuszczonym powyżej, gdy tymczasem pragnienia takim normom nie podlegają.

4. Możemy wpływać na zamiary, lecz nie możemy wpływać na pragnienia.

5. Ponieważ 1., pragnienia są z konieczności egoistyczne, zamiary zaś nie są. 


\section{Uwaga końcowa}

Jestem pewien, że każdy może rozważyć przedstawione tutaj rozróżnienia, obserwując i analizując własne doświadczenia. 0 ile jednak mam rację, rozróżnienia te będą znacząco wpływać na teorię działania. Jeśli będziemy wyjaśniać działanie przywołując pragnienia, eksplanacja będzie przybierać znamiona deterministyczne. Jeśli jednak, z drugiej strony, będziemy wyjaśniać działanie przywołując zamiary żywione przez podmiot, działanie będzie wynikać z wolnego wyboru i odwoływać się także do odpowiedzialności podmiotu za jego dokonanie. Przeznaczeniem człowieka jest dokonywać obydwa rodzaje działań.

Z jęz. angielskiego przełożyła Aleksandra Mathiesen

\section{Literatura}

Arystoteles, 1988. O duszy. Tłum. P. Siwek. Warszawa: PWN.

Davidson, R. 1980. Essays on Actions and Events. Oxford: Oxford University Press.

Hieke, A. 2006. Pragmatische Selbstwidersprüchlichkeit und pragmatische Analytizität. Sankt Augustin: Academia Verlag.

Hume, D. 1963. Traktat o naturze ludzkiej. Tłum. Cz. Znamierowski. Warszawa: PWN.

Kenny, A. 1963. Action, Emotion and Will. Bristol: Thoemmes.

-_- 1966. "Intention and Purpose." Journal of Philosophy 63: 642-651.

- - 1973. The Anatomy of the Soul. Historical Essays in the Philosophy of Mind. Oxford: Blackwell.

Moore, G. E. 1942. "A Reply to my Critics." In Schilpp, P. A. (Ed.), The Philosophy of G. E. Moore. La Salle, III: Open Court Publishing, pp. 533688.

- - . 1944. "Russell's 'Theory of Descriptions'." In Schilpp, P. A. (Ed.), The Philosophy of Bertrand Russell. La Salle, III: Open Court Publishing, pp. 177-225.

Roughley, N. 2006. Wanting and Intending, Elements of a Philosophy of Practical Mind (unpublished manuscript).

Seel, G. 2004. "Décision et Rationalité." In Esfeld, M. \& Tétaz. J.-M. (Eds.), Généalogie de la pensée moderne. Volume d'hommages à Ingeborg Schüssler. Frankfurt/Main: Ontos Verlag, pp. 396-412.

Smith, M. 1994. The Moral Problem. Oxford: Clarendon Press. 
Williams, B. 1970. “Deciding to Believe." In Problems of the Self. Philosophical Papers 1956-1972. Cambridge: Cambridge University Press, pp. 136151. 
Gerhard Seel (Bern)

\title{
Pragnienie i zamiar - przyczynek do dystynkcji pojęć What is the Difference Between Desiring and Intending?
}

\begin{abstract}
To answer the title question there has been initially introduced the elements of the Aristotle theory in order to confront it with the concepts of the linguistic paradigm philosophers. Finally, the author proposes a very own solution to this dilemma. Accordingly to the methodology of the linguistic paradigm, the paper brings about an analyse of the linguistic expressions to investigate whether they provide a sufficient premise to distinguish between desires and intentions. The author asks several questions which help him describe desires, and them confront achieved characteristics with the essential features of intentions. In conclusion, the paper put forward the case of the explanation of actions according to both desires and intentions.
\end{abstract}

Keywords: Desire, intention, believe, action, Aristotle

Doi: $10.14746 /$ eip.2014.2.3 